\title{
Defluvicoccus vanus gen. nov., sp. nov., a novel Gram-negative coccus/coccobacillus in the 'Alphaproteobacteria' from activated sludge
}

Correspondence
R. J. Seviour
r.seviour@latrobe.edu.au

The application of molecular techniques to the study of activated sludge systems has revealed the presence of many previously uncultured bacteria (Seviour \& Blackall, 1999; Loy et al., 2002; Wagner \& Loy, 2002). However, the techniques have not always provided a clearer explanation for how these systems might operate, a comment particularly relevant to processes of enhanced biological phosphorus removal (EBPR) (Loy et al., 2002; Seviour et al., 2003). Molecular studies on community structure of EBPR systems suggest that members of the Actinobacteria and 'Betaproteobacteria' closely related to members of the genus Rhodocyclus are probably responsible for phosphate removal

tPresent address: Environmental Engineering Research Centre, School of Civil and Environmental Engineering, Nanyang Technological University, Singapore 639798.

Abbreviations: EBPR, enhanced biological phosphorus removal; GAO, glycogen-accumulating organisms; PAO, polyphosphate-accumulating organisms; PHA, poly- $\beta$-hydroxyalkanoate; polyP, polyphosphate; TFO, tetrad-forming organisms.

The GenBank/EMBL/DDBJ accession number for the $16 \mathrm{~S}$ rRNA gene sequence of strain Ben $114^{\top}$ is AF179678. in some sludge plants (Hesselmann et al., 1999; Crocetti et al., 2000; Zilles et al., 2002; Seviour et al., 2003). There is some evidence that other bacteria under certain conditions can out-compete the polyphosphate-accumulating organisms $(\mathrm{PAO})$ during anaerobic substrate uptake, eventually leading to accumulation of glycogen-like carbohydrates instead of polyphosphate (polyP). Bacteria referred to as the 'glycogen-accumulating organisms' (GAO) are one such group (Seviour et al., 2000; Crocetti et al., 2002). They were originally called 'G-bacteria' because they dominated plants fed glucose (Cech \& Hartman, 1993), and exist often as distinctive coccal cells in tetrads or clusters (Seviour et al., 2000). Pure cultures of these tetrad-forming organisms (TFO) from different countries were described as separate species of a novel genus Amaricoccus, in subgroup 3 of the 'Alphaproteobacteria' (Maszenan et al., 1997). Several other phylogenetically different TFO have also been isolated from activated sludge (Nakamura et al., 1995; Yoshimi et al., 1996; Maszenan et al., 1999a, b, 2000). Some, like the actinobacterial Tetrasphaera species (Maszenan et al., 2000) and the betaproteobacterium Quadricoccus australiensis (Maszenan et al., 2002), appear to accumulate polyP in 
pure culture. However, their importance, if any, in EBPR plants remains unclear (Seviour et al., 2003).

Here we describe a novel Gram-negative TFO (designated strain Ben $114^{\mathrm{T}}$ ) isolated from a sample of biomass from an EBPR activated sludge plant in the Czech Republic. 16S rRNA gene sequence analysis indicates that this organism is a member of the 'Alphaproteobacteria', but different from Amaricoccus species (Maszenan et al., 1997) and Q. australiensis (Maszenan et al., 2002) and with no known close relatives. We propose that it be placed in a new genus, Defluvicoccus gen. nov., as Defluvicoccus vanus sp. nov., representing a new phylogenetic lineage within subgroup 1 of the 'Alphaproteobacteria' (Woese et al., 1984; Woese, 1987).

Strain Ben $114^{\mathrm{T}}$ was isolated by micromanipulation from a sample of activated sludge biomass from an EBPR plant in Pilsen, Czech Republic, in August 1997 (Maszenan et al., 1997). This EBPR plant had just started operation and good phosphate removal had not been achieved when the sample was obtained. Of many media routinely used to culture organisms from activated sludge that were tested (Maszenan et al., 1997), freshly prepared GS medium (Williams \& Unz, 1985) was the most successful in supporting growth of this organism from activated sludge. Purity of the cultures that grew was checked by light microscopic examination of single colonies, and only those consisting of distinctive TFO cells were then recovered for characterization. Strain Ben $114^{\mathrm{T}}$ was stored at $-80^{\circ} \mathrm{C}$ (Maszenan et al., 1997). The methods used for determining substrate utilization patterns, temperature and $\mathrm{pH}$ responses and biochemical characteristics were those described previously (Maszenan et al., 1997), as were the staining methods used to identify polyP and poly$\beta$-hydroxyalkanoate (PHA). Cells used to inoculate Biolog, API ZYM and Microbact 24E kits were grown on GS agar for 3 weeks at $25^{\circ} \mathrm{C}$. These characterizations were repeated in triplicate and always gave the same results. Genomic DNA $\mathrm{G}+\mathrm{C}$ base composition was determined by HPLC with the method described by Janssen et al. (1996). Amplification of the 16S rRNA gene and its sequencing used the techniques detailed in Maszenan et al. (1997). Phylogenetic analysis after sequence alignment (Patel et al., 1995) employed several methods described in the PHYLIP package (Felsenstein, 1993) including DNADIST (Jukes \& Cantor, 1969) and neighbour-joining software. Trees were generated using TREECON after bootstrap and transversion analysis (van de Peer \& de Wachter, 1993).

Strain Ben $114^{\mathrm{T}}$ grew very slowly on GS agar, taking 2-3 weeks to produce visible mucoid beige colonies of $<5 \mathrm{~mm}$ diameter. In GS broth dispersed growth was seen. Cocci/coccobacilli were irregular in size $(1 \cdot 5-4 \cdot 0 \mu \mathrm{m})$, usually growing in tetrads or clusters (Fig. 1), and the cells always showed Gram-negative staining. However, after staining with this and several other stains like methylene blue and toluidine blue, cells had a distinctive 'ghost-like' appearance (Fig. 1), which was much more apparent than was sometimes seen with Amaricoccus (Maszenan et al.,

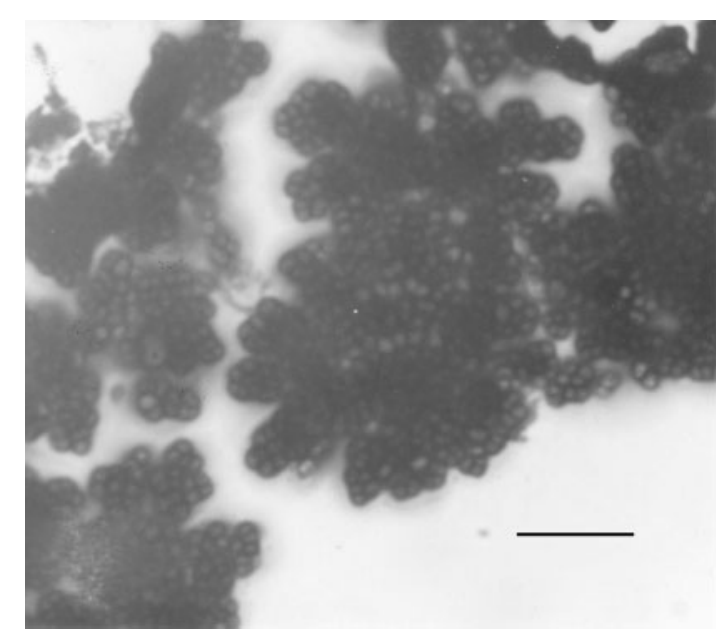

Fig. 1. Light micrograph of strain Ben $114^{\top}$ grown on GS medium showing clustered cells and unstained cell contents after polyP staining using the method of Rees et al. (1992). Bar, $10 \mu \mathrm{m}$.

1997). No polyP was detected by staining, but an abundance of intracellular PHA granules was apparent after staining with Nile blue A (Rees et al., 1992), when cells were grown aerobically on acetate, propionate or glucose (Maszenan et al., 1997).

As mentioned above, Ben $114^{\mathrm{T}}$ is a very slow-growing organism, and many of the biochemical tests used here produced negative results even after prolonged incubation, probably as a consequence of this. Ben $114^{\mathrm{T}}$ is oxidasenegative, catalase-positive and weakly urease-positive. It failed to produce positive reactions with any of the Microbact $24 \mathrm{E}$ system tests (Oxoid), except that it was weakly positive for gelatin liquefaction. The following substrates were utilized with Biolog GN and GP systems: L-arabinose (weak), D-psicose, D-xylose (weak), $\alpha$-DL-hydroxybutyrate, adonitol, D-lactic acid methyl ester, D-malate, methyl pyruvate, pyruvate, $N$-acetylglutamate, $N$-acetyl-D-glucosamine, i-erythritol, succinate, $\alpha$-D-glucose, methyl $\beta$-D-glucoside, D-fructose (weak), monomethyl succinate (weak), methyl $\alpha$-D-glucoside (weak), stachyose (weak), acetate, $\beta$-DLhydroxybutyrate, lactamide (weak), L-lactate, L-malate, propionate, succinate, L-glutamate, L-threonine, quinate, L-aspartate, 3 -methyl glucose, $\alpha$-ketovalerate (weak), Dsorbitol (weak) and putrescine (weak).

With the API ZYM system, strain Ben $114^{\mathrm{T}}$ was positive for the following enzyme activities: alkaline phosphatase, esterase (C4), esterase lipase (C8), lipase (C14), leucine arylamidase, acid phosphatase and naphthol-AS-BIphosphohydrolase. It was negative for valine arylamidase, cystine arylamidase, trypsin, chymotrypsin, $\alpha$-galactosidase, $\beta$-galactosidase, $\quad N$-acetyl- $\beta$-glucosidase, $\alpha$-mannosidase and $\alpha$-fucosidase. It grew optimally at $25-30{ }^{\circ} \mathrm{C}$ and at a $\mathrm{pH}$ of $7 \cdot 5-8 \cdot 0$. The DNA G $+\mathrm{C}$ composition was determined as $66 \mathrm{~mol} \%$ (Table 1). 
Table 1. Comparative phenotypic characteristics of strain Ben $114^{\top}$ and selected genera of subgroup 1 of the 'Alphaproteobacteria'

Data for reference taxa were taken from Falk et al. (1985), Reinhold et al. (1987), Tarrand et al. (1978) and Krieg \& Döbereiner (1984) (Azospirillum), Imhoff et al. (1998) (Rhodospirillum), Favinger et al. (1989) and Kawasaki et al. (1992) (Rhodocista), Pfennig et al. (1997) (Rhodospira) and Maratea \& Blakemore (1981), Schleifer et al. (1991) and Burgess et al. (1993) (Magnetospirillum). +, Positive; -, negative; ND, not determined; NA, not available.

\begin{tabular}{|c|c|c|c|c|c|c|}
\hline Characteristic & Strain Ben $114^{\mathrm{T}}$ & Azospirillum & Rhodospirillum & Rhodocista & Rhodospira & Magnetospirillum \\
\hline $\begin{array}{l}\text { Morphology } \\
\text { (cell size, } \mu \mathrm{m})\end{array}$ & $\begin{array}{l}\text { Cocci/coccobacilli in } \\
\text { tetrads and clusters } \\
(1 \cdot 5-4 \cdot 5)\end{array}$ & $\begin{array}{l}\text { Straight to slightly curved } \\
\text { rods }(0 \cdot 7-1 \cdot 4)\end{array}$ & $\begin{array}{l}\text { Spiral shaped cells } \\
(0 \cdot 8-1 \cdot 0)\end{array}$ & $\begin{array}{l}\text { Spirilloid }(1 \cdot 0-2 \cdot 0) \text {, vibrioid } \\
\text { cells, cyst-forming bacteria }\end{array}$ & $\begin{array}{l}\text { Spirilloid with one S-turn, } \\
\text { vibrioid }(0 \cdot 6-0 \cdot 8)\end{array}$ & Helical cells $(0 \cdot 2-0 \cdot 7)^{\star}$ \\
\hline $\begin{array}{l}\text { Polysaccharide } \\
\text { granules }\end{array}$ & ND & NA & + & + & NA & NA \\
\hline Motility & Non-motile & Motile & Motile & Motile & Motile & Motile \\
\hline Flagella & Absent & $\begin{array}{l}\text { Single, polar in liquid } \\
\text { medium, polytrichous } \\
\text { on solid media }\end{array}$ & Bipolar tufts & Polar flagella & Bipolar flagellar tufts & Single bipolar flagellum \\
\hline $\begin{array}{l}\text { DNA G }+\mathrm{C} \\
\text { content }(\mathrm{mol} \%)\end{array}$ & 66 & $67-71$ & $63-66$ & $69-70$ & $65 \cdot 7$ & $64-71^{*}$ \\
\hline Oxidase & - & + & + & + & NA & $+^{*}$ \\
\hline Catalase & + & + & + & + & ND & $+^{*}$ \\
\hline Habitat & Activated sludge biomass & $\begin{array}{l}\text { Soils and roots of cereal } \\
\text { crops, grasses and } \\
\text { tuber plants }\end{array}$ & Mud or water & $\begin{array}{l}\text { Water sample (temperature } \\
55^{\circ} \mathrm{C} \text { ) at the edge of source } \\
\text { pool, Thermopolis Hot } \\
\text { Springs, WY, USA }\end{array}$ & $\begin{array}{l}\text { Microbial mats from Great } \\
\text { Sippewissett salt marsh, } \\
\text { Cape Cod, MA, USA }\end{array}$ & $\begin{array}{l}\text { Freshwater sources includ- } \\
\text { ing distilled water, ditch } \\
\text { and canal water and } \\
\text { sewage }\end{array}$ \\
\hline $\mathrm{O}_{2}$ requirement & Aerobic & Aerobic & $\begin{array}{l}\text { Anaerobic in light, } \\
\text { aerobic to micro- } \\
\text { aerophilic in dark }\end{array}$ & Aerobic and microaerophilic & Strictly anoxic & Microaerophilic $^{\star}$ \\
\hline $\begin{array}{l}\text { Optimum temper- } \\
\text { ature }\left({ }^{\circ} \mathrm{C}\right)\end{array}$ & $25-30$ & $34-37 \dagger$ & NA & $39-45$ & $\begin{array}{l}25-30(\text { at } 2 \% \mathrm{NaCl}), 20-35 \\
\quad \text { (at } 0 \cdot 5-5 \cdot 0 \% \mathrm{NaCl})\end{array}$ & 30 \\
\hline Optimum pH & $7 \cdot 5-8 \cdot 0$ & $5 \cdot 8-6 \cdot 8 \dagger$ & NA & $6 \cdot 8$ & $\begin{array}{c}7 \cdot 3-7 \cdot 5(\text { at } 2 \% \mathrm{NaCl}), 7 \cdot 0- \\
7 \cdot 8(\text { at } 0 \cdot 5-5 \cdot 0 \% \mathrm{NaCl})\end{array}$ & NA \\
\hline Urease & + & + & NA & NA & NA & - \\
\hline Nitrate reduction & + (weak) & + & - & NA & NA & + \\
\hline Gelatin hydrolysis & + (weak) & - & NA & NA & NA & - \\
\hline
\end{tabular}

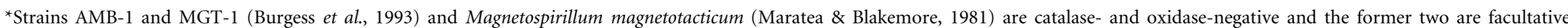
anaerobes. Data from Schleifer et al. (1991).

$\dagger$ Except for Azospirillum halopraeferans, which has an optimal temperature of $41^{\circ} \mathrm{C}$ and optimal $\mathrm{pH}$ of $8 \cdot 0$. 


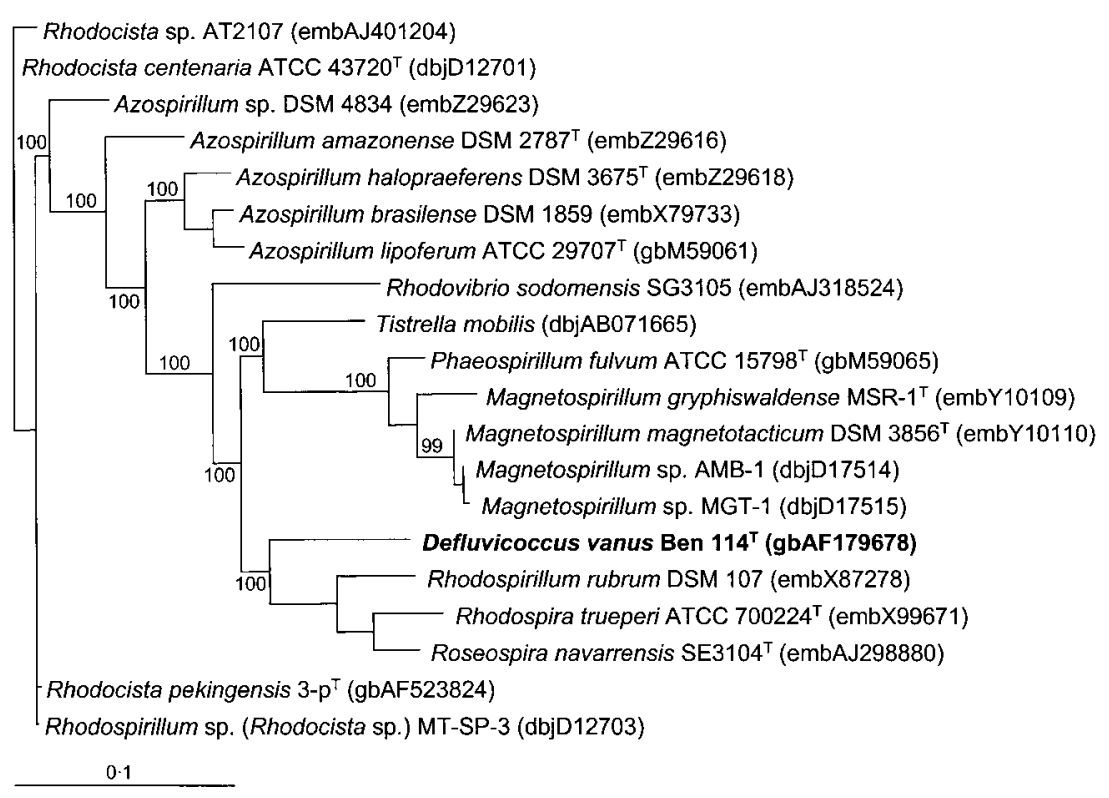

Fig. 2. Phylogenetic tree based on $16 \mathrm{~S}$ rRNA gene sequence analysis of strain Ben $114^{\top}$ showing its relationship to other members of subgroup 1 of the 'Alphaproteobacteria', constructed using the neighbour-joining method. All sequences were obtained from the Ribosomal Database Project except for Rhodospira trueperi, which was extracted from GenBank. Bootstrap values from 100 replicates are indicated at branch points. Bar, 10 nucleotide substitutions per 100 nucleotides.
On the basis of 1212 nucleotides, phylogenetic analysis (Fig. 2) revealed that Ben $114^{\mathrm{T}}$ is a member of subgroup 1 of the 'Alphaproteobacteria', with no close relatives among recognized organisms in this class. This phylogeny was robust, as supported by high bootstrap values and stability after transversion analysis. The neighbour-joining tree shows that strain Ben $114^{\mathrm{T}}$ does not fall within the currently proposed alphaproteobacterial groupings, i.e. the Rhodospirillum rubrum (Molisch, 1907; Imhoff et al., 1998), Phaeospirillum fulvum (Imhoff et al., 1998) and Magnetospirillum gryphiswaldense groupings (Maidak et al., 1999). Its $16 \mathrm{~S}$ rRNA gene sequence showed similarities of up to $87.5 \%$ to that of the Rhodospirillum rubrum group, up to $88.5 \%$ to the P. fulvum group, $88 \cdot 2 \%$ to M. gryphiswaldense (Schleifer et al., 1991; Burgess et al., 1993), 88.5\% to Magnetospirillum magnetotacticum (Maratea \& Blakemore, 1981; Eden et al., 1991; Schleifer et al., 1991; Burgess et al., 1993 ) and $89 \%$ to Rhodocista centenaria (Favinger et al., 1989; Kawasaki et al., 1992). A comparison of the inferred 16S rRNA gene sequence signature nucleotides between members of subgroup 1 of the 'Alphaproteobacteria' supports the view that Ben $114^{\mathrm{T}}$ is not closely related to any of them. For example, only strain Ben $114^{\mathrm{T}}$ possessed U-A, G-U, UG and G-U at Escherichia coli positions 333-366, 425-434, 436-441 and 1218-1223, respectively (Table 2).

The isolation and characterization of strain Ben $114^{\mathrm{T}}$ has extended the number and hence the extent of the phylogenetic diversity of the TFO reported in activated sludge systems (Seviour et al., 2000). Earlier work in our laboratories (Maszenan et al., 1999a, b, 2000) and elsewhere (Nakamura et al., 1995; Yoshimi et al., 1996; Shintani et al., 2000) has revealed the presence of several novel Grampositive cocci in this complex ecosystem (Seviour et al., 2000). Although their roles and functions there are not well understood, it is possible from their pure culture behaviour that some may participate in EBPR (Nakamura et al., 1995; Maszenan et al., 1999a, b, 2000).

Nielsen et al. (1999), Crocetti et al. (2002) and Kong et al. (2002) all reported novel Gram-negative cocci in activated sludge with poor EBPR capacity, which were identified after fluorescence in situ hybridization as members of the 'Gammaproteobacteria'. Strain Ben $114^{\mathrm{T}}$ is clearly phylogenetically different from these isolates, but, like the Amaricoccus isolates (Maszenan et al., 1997) and these gammaproteobacteria, it appears unable to accumulate polyP. However, its ability to synthesize PHA aerobically in pure culture is not consistent with the phenotype of a GAO (Hesselmann et al., 1999; Crocetti et al., 2002; Seviour et al., 2003).

Phylogenetic analysis of the $16 \mathrm{~S}$ rRNA gene sequence of Ben $114^{\mathrm{T}}$ (Fig. 2) shows that it is a novel, deeply branching member of the 'Alphaproteobacteria' with no recognized close relatives, a proposal supported based on differences in the phenotypic characteristics of these taxa (Table 1) and inferred 16S rRNA gene sequence signature nucleotides (Table 2). The data presented support the view that strain Ben $114^{\mathrm{T}}$ is representative of a new genus and species, for which the name Defluvicoccus vanus gen. nov., sp. nov. is proposed. Because of its low level of similarity to recognized members of this division, it is proposed that Defluvicoccus is a member of a novel phylogenetic lineage within subgroup 1 of the 'Alphaproteobacteria' (Woese et al., 1984; Woese, 1987), separate from both the P. fulvum and the Rhodospirillum rubrum lineages (Imhoff et al., 1998).

Reclassification of the spiral-shaped, phototrophic, purple, non-sulfur bacteria of the 'Alphaproteobacteria' by Imhoff et al. (1998) has led to the description of several novel species and genera. The signature 16S rRNA gene sequence nucleotides suggested by Woese (1987) to delineate the 


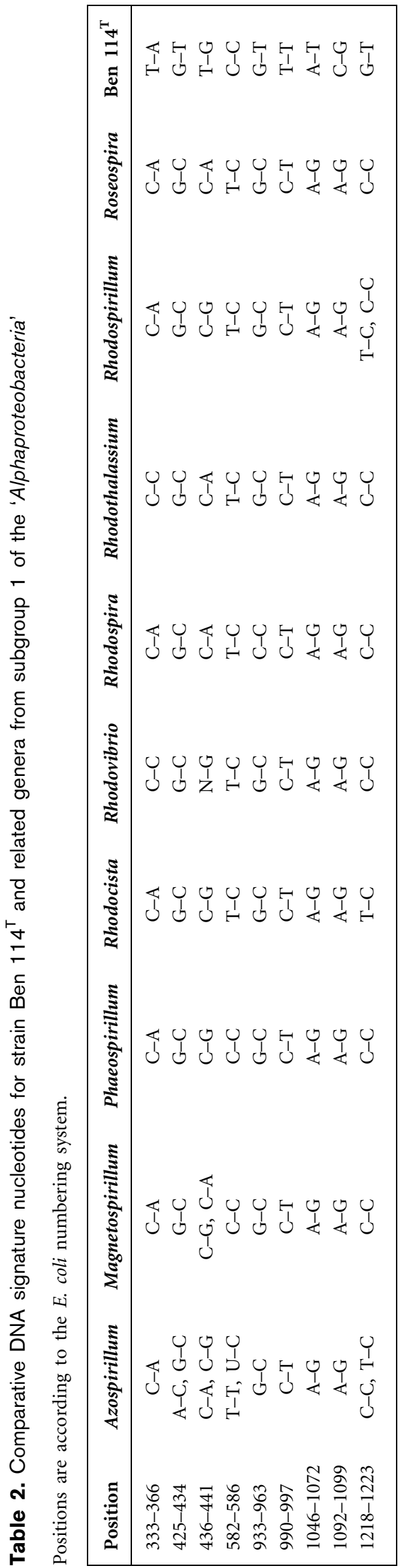

'Alphaproteobacteria' are generally still applicable and strain Ben $114^{\mathrm{T}}$ possesses all of these (data not shown). However, a few modifications to the scheme of Woese (1987) are required in order to accommodate these newly described taxa. For example, at position 812 Roseospira (Kompantseva \& Gorlenko, 1984; Imhoff et al., 1998) has $\mathrm{U}$ instead of G, while at position 933 Rhodospira (Pfennig et al., 1997) possesses C instead of G. In addition, at position 822 Rhodothalassium (Drews, 1981; Imhoff et al., 1998) has $\mathrm{G}$ instead of A or U, and at position 823 Rhodocista (Favinger et al., 1989; Kawasaki et al., 1992) has C instead of G or A.

\section{Description of Defluvicoccus gen. nov.}

Defluvicoccus [De.flu.vi.coc'cus. L. neut. n. defluvium sewage; N.L. (Gr. derived) masc. n. coccus berry (spherical microbe); N.L. masc. n. Defluvicoccus a coccus from sewage].

Produces mucoid beige colonies $<5 \mathrm{~mm}$ in diameter after 3-4 weeks incubation at $25^{\circ} \mathrm{C}$ on GS medium. Gramnegative, chemoheterotrophic, non-spore-forming, nonmotile and aerobic cocci/coccobacilli (mean cell diameter $1 \cdot 5-4 \cdot 0 \mu \mathrm{m})$, which are usually arranged in clusters or tetrads. Cells stain very faintly and appear empty after staining. Oxidase-negative and catalase-positive. The type species is Defluvicoccus vanus.

\section{Description of Defluvicoccus vanus sp. nov.}

Defluvicoccus vanus (va' nus. L. masc. adj. vanus empty, idle, pertaining to its staining behaviour).

Shows the following properties in addition to those included in the genus description. No polyP granules can be detected in axenic cultures, although glucose-, acetate- and propionate-grown cells contain PHA granules. The following substrates are utilized: L-arabinose, D-psicose, D-xylose, $\alpha$-DL-hydroxybutyrate, adonitol, D-lactic acid methyl ester, D-malate, methyl pyruvate, pyruvate, $\mathrm{N}$-acetylglutamate, i-erythritol, succinate, $\alpha$-ketovalerate, D-sorbitol, putrescine, methyl $\alpha$-D-mannoside, stachyose, acetate, $\beta$-DLhydroxybutyrate, lactamide, L-lactate, L-malate, propionate, L-glutamate, L-threonine, quinate, L-aspartate, D-fructose, $\alpha$-D-glucose, 3 -methyl glucose, methyl $\beta$-D-glucoside and monomethyl succinate. Positive for the following enzyme activities as detected with the API ZYM system: alkaline phosphatase, esterase, esterase lipase, leucine arylamidase, acid phosphatase and naphthol-AS-BIphosphohydrolase. Growth occurs at temperatures between 20 and $30^{\circ} \mathrm{C}$ and at $\mathrm{pH}$ values between $5 \cdot 0$ and $8 \cdot 5$. Weakly positive for urease and gelatin liquefaction. Does not produce $\mathrm{H}_{2} \mathrm{~S}$, indole or acetoin. The DNA G $+\mathrm{C}$ content is $66 \mathrm{~mol} \%$.

The type strain, Ben $114^{\mathrm{T}} \quad\left(=\mathrm{NCIMB} 13612^{\mathrm{T}}=\mathrm{CIP}\right.$ $\left.107350^{\mathrm{T}}\right)$, was isolated from activated sludge. 


\section{Acknowledgements}

A.M.M. was supported by an LUPRS and LUOPRS scholarship. A La Trobe University Central Grant and an ARC Large Grant to R. J.S. supported this work. We thank Professor H. G. Trüper for his assistance with naming of the organism.

\section{References}

Burgess, J. G., Kawaguchi, R., Sakaguchi, T., Thornhill, R. H. \& Matsunaga, T. (1993). Evolutionary relationships among Magnetospirillum strains inferred from phylogenetic analysis of $16 \mathrm{~S}$ rDNA sequences. J Bacteriol 175, 6689-6694.

Cech, J. S. \& Hartman, P. (1993). Competition between polyphosphate and polysaccharide accumulating bacteria in enhanced biological phosphate removal systems. Water Res 27, 1219-1225.

Crocetti, G. R., Hugenholtz, P., Bond, P. L., Schuler, A., Keller, J., Jenkins, D. \& Blackall, L. L. (2000). Identification of polyphosphateaccumulating organisms and design of 16S rRNA directed probes for their detection and quantitation. Appl Environ Microbiol 66, $1175-1182$.

Crocetti, G. R., Banfield, J. F., Keller, J., Bond, P. L. \& Blackall, L. L. (2002). Glycogen-accumulating organisms in laboratory-scale and full-scale wastewater treatment processes. Microbiology 148, 3353-3364.

Drews, G. (1981). Rhodospirillum salexigens, spec. nov., an obligately halophilic phototrophic bacterium. Arch Microbiol 130, 325-327.

Eden, P. A., Schmidt, T. M., Blakemore, R. P. \& Pace, N. R. (1991). Phylogenetic analysis of Aquaspirillum magnetotacticum using polymerase chain reaction-amplified $16 \mathrm{~S}$ rRNA-specific DNA. Int J Syst Bacteriol 41, 324-325.

Falk, E. C., Döbereiner, J., Johnson, J. L. \& Krieg, N. R. (1985). Deoxyribonucleic acid homology of Azospirillum amazonense Magalhães et al. 1984 and emendation of the description of the genus Azospirillum. Int J Syst Bacteriol 35, 117-118.

Favinger, J., Stadtwald, R. \& Gest, H. (1989). Rhodospirillum centenum, sp nov., a thermotolerant cyst-forming anoxygenic photosynthetic bacterium. Antonie van Leeuwenhoek 55, 291-296.

Felsenstein, J. (1993). PHYLIP (phylogenetic inference package), version 3.51c. Distributed by the author. Department of Genome Sciences, University of Washington, Seattle, USA.

Hesselmann, R. P. X., Werlen, C., Hahn, D., van der Meer, J. R. \& Zehnder, A. J. B. (1999). Enrichment, phylogenetic analysis and detection of a bacterium that performs enhanced biological phosphate removal in activated sludge. Syst Appl Microbiol 22, 454-465.

Imhoff, J. F., Petri, R. \& Süling, J. (1998). Reclassification of species of the spiral-shaped phototrophic purple non-sulfur bacteria of the $\alpha$-Proteobacteria: description of the new genera Phaeospirillum gen. nov., Rhodovibrio gen. nov., Rhodothalassium gen. nov. and Roseospira gen. nov. as well as transfer of Rhodospirillum fulvum to Phaeospirillum fulvum comb. nov., of Rhodospirillum molischianum to Phaeospirillum molischianum comb. nov., of Rhodospirillum salinarum to Rhodovibrio salinarum comb. nov., of Rhodospirillum sodomense to Rhodovibrio sodomensis comb. nov., of Rhodospirillum salexigens comb. nov. to Rhodothalassium salexigens comb. nov. and of Rhodospirillum mediosalinum to Roseospira mediosalina comb. nov. Int J Syst Bacteriol 48, 793-798.

Janssen, P. H., Liesack, W., Kluge, C., Seeliger, S., Schink, B. \& Harfoot, C. G. (1996). Sodium-dependent succinate decarboxylation by a new anaerobic bacterium belonging to the genus Peptostreptococcus. Antonie van Leeuwenhoek 70, 11-20.
Jukes, T. H. \& Cantor, C. R. (1969). Evolution of protein molecules. In Mammalian Protein Metabolism, pp. 21-132. Edited by H. N. Munro. New York: Academic Press.

Kawasaki, H., Hoshino, Y., Kuraishi, H. \& Yamasato, K. (1992). Rhodocista centenaria gen. nov., sp. nov., a cyst-forming anoxygenic photosynthetic bacterium and its phylogenetic position in the Proteobacteria alpha group. J Gen Appl Microbiol 38, 541-551.

Kompantseva, E. I. \& Gorlenko, V. M. (1984). A new species of moderately halophilic purple bacterium Rhodospirillum mediosalinum sp. nov. Mikrobiologiia 53, 954-961 (in Russian).

Kong, Y., Ong, S. L., Ng, W. J. \& Liu, W. T. (2002). Diversity and distribution of a deeply branched novel proteobacterial group found in anaerobic-aerobic activated sludge processes. Environ Microbiol 4, 753-757.

Krieg, N. R. \& Döbereiner, J. (1984). Genus Azospirillum Tarrand, Krieg and Döbereiner 1979, $79^{\mathrm{AL}}$. In Bergey's Manual of Systematic Bacteriology, vol. 1, pp. 94-104. Edited by N. R. Krieg \& J. G. Holt. Baltimore: Williams \& Wilkins.

Loy, A., Daims, H. \& Wagner, M. (2002). Activated sludge molecular techniques for determining community composition. In Encyclopaedia for Environmental Microbiology, pp. 26-43. Edited by G. Bitton. New York: Wiley Scientific.

Maidak, B. L., Cole, J. R., Parker, C. T., Jr \& 11 other authors (1999). A new version of the RDP (Ribosomal Database Project). Nucleic Acids Res 27, 171-173.

Maratea, D. \& Blakemore, R. P. (1981). Aquaspirillum magnetotacticum sp. nov., a magnetic spirillum. Int J Syst Bacteriol 31, 452-455.

Maszenan, A. M., Seviour, R. J., Patel, B. K. C., Rees, G. N. \& McDougall, B. M. (1997). Amaricoccus gen. nov., a gram-negative coccus occurring in regular packages or tetrads, isolated from activated sludge biomass, and descriptions of Amaricoccus veronensis sp. nov., Amaricoccus tamworthensis sp. nov., Amaricoccus macauensis sp. nov., and Amaricoccus kaplicensis sp. nov. Int J Syst Bacteriol 47, 727-734.

Maszenan, A. M., Seviour, R. J., Patel, B. K. C., Schumann, P. \& Rees, G. N. (1999a). Tessaracoccus bendigoensis gen. nov., sp. nov., a Gram-positive coccus occurring in regular packages or tetrads, isolated from activated sludge biomass. Int J Syst Bacteriol 49, 459-468.

Maszenan, A. M., Seviour, R. J., Patel, B. K. C., Schumann, P., Burghardt, J., Webb, R. I., Soddell, J. A. \& Rees, G. N. (1999b). Friedmanniella spumicola sp. nov. and Friedmanniella capsulata sp. nov. from activated sludge foam: Gram-positive cocci that grow in aggregates of repeating groups of cocci. Int J Syst Bacteriol 49, 1667-1680.

Maszenan, A. M., Seviour, R. J., Patel, B. K. C., Schumann, P., Burghardt, J., Tokiwa, Y. \& Stratton, H. M. (2000). Three isolates of novel polyphosphate-accumulating Gram-positive cocci, obtained from activated sludge, belong to a new genus, Tetrasphaera gen. nov., and description of two new species, Tetrasphaera japonica sp. nov. and Tetrasphaera australiensis sp. nov. Int J Syst Evol Microbiol 50, 593-603.

Maszenan, A. M., Seviour, R. J., Patel, B. K. C. \& Schumann, P. (2002). Quadricoccus australiensis gen. nov., sp. nov., a $\beta$ proteobacterium from activated sludge biomass. Int $J$ Syst Evol Microbiol 52, 223-228.

Molisch, H. (1907). Die Purpurbakterien nach neuen Untersuchungen. Jena: G. Fischer (in German).

Nakamura, K., Hiraishi, A., Yoshimi, Y., Kawaharasaki, M., Masuda, K. \& Kamagata, Y. (1995). Microlunatus phosphovorus gen. nov., sp. nov., a new gram-positive polyphosphate-accumulating bacterium isolated from activated sludge. Int J Syst Bacteriol 45, 17-22. 
Nielsen, A. T., Liu, W.-T., Filipe, C., Grady, L., Jr, Molin, S. \& Stahl, D. A. (1999). Identification of a novel group of bacteria in sludge from a deteriorated biological phosphorus removal reactor. Appl Environ Microbiol 65, 1251-1258.

Patel, B. K. C., Andrews, K. T., Ollivier, B., Mah, R. A. \& Garcia, J. L. (1995). Reevaluating the classification of Halobacteriodes and Haloanaerobacter species based on sequence comparisons of the 16S ribosomal RNA gene. FEMS Microbiol Lett 134, 115-119.

Pfennig, N., Lünsdorf, H., Süling, J. \& Imhoff, J. F. (1997). Rhodospira trueperi gen. nov., spec. nov., a new phototrophic proteobacterium of the alpha group. Arch Microbiol 168, 39-45.

Rees, G. N., Vasiliadis, G., May, J. W. \& Bayly, R. C. (1992). Differentiation of polyphosphate and poly- $\beta$-hydroxybutyrate granules in an Acinetobacter sp. isolated from activated sludge. FEMS Microbiol Lett 94, 171-174.

Reinhold, B., Hurek, T., Fendrik, I., Pot, B., Gillis, M., Kersters, K., Thielemans, S. \& De Ley, J. (1987). Azospirillum halopraeferens sp. nov., a nitrogen-fixing organism associated with roots of Kallar grass (Leptochloa fusca (L.) Kunth). Int J Syst Bacteriol 37, 43-51.

Schleifer, K.-H., Schüler, D., Spring, S., Weizenegger, M., Amann, R., Ludwig, W. \& Köhler, M. (1991). The genus Magnetospirillum gen. nov.: description of Magnetospirillum gryphiswaldense sp. nov. and transfer of Aquaspirillum magnetotacticum to Magnetospirillum magnetotacticum comb. nov. Syst Appl Microbiol 14, 379-385.

Seviour, R. J. \& Blackall, L. L. (1999). Microbiology of Activated Sludge. Dordrecht: Kluwer Academic.

Seviour, R. J., Maszenan, A. M., Soddell, J. A., Tandoi, V., Patel, B. K. C., Kong, Y. \& Schumann, P. (2000). Microbiology of the 'Gbacteria' in activated sludge. Environ Microbiol 2, 581-593.

Seviour, R. J., Mino, T. \& Onuki, M. (2003). The microbiology of biological phosphorus removal in activated sludge systems. FEMS Microbiol Rev 27, 99-127.
Shintani, T., Liu, W.-T., Hanada, S., Kamagata, Y., Miyaoka, S., Suzuki, Y. \& Nakamura, K. (2000). Micropruina glycogenica gen. nov., sp. nov., a new Gram-positive glycogen-accumulating bacterium isolated from activated sludge. Int J Syst Evol Microbiol 50, 201-207.

Tarrand, J. J., Krieg, N. R. \& Döbereiner, J. (1978). A taxonomic study of the Spirillum lipoferum group, with descriptions of a new genus, Azospirillum gen. nov. and two species, Azospirillum lipoferum (Beijerinck) comb. nov. and Azospirillum brasilense sp. nov. Can $J$ Microbiol 24, 967-980.

van de Peer, Y. \& de Wachter, R. (1993). TREECON: a software package for the construction and drawing of evolutionary trees. Comput Appl Biosci 9, 177-182.

Wagner, M. \& Loy, A. (2002). Bacterial community composition and function in sewage treatment systems. Curr Opin Biotechnol 13, 218-227.

Williams, T. M. \& Unz, R. F. (1985). Isolation and characterization of filamentous bacteria present in bulking activated sludge. Appl Environ Microbiol 22, 273-282.

Woese, C. R. (1987). Bacterial evolution. Microbiol Rev 51, 221-271.

Woese, C. R., Stackebrandt, E., Weisburg, W. G. \& 8 other authors (1984). The phylogeny of purple bacteria: the alpha subdivision. Syst Appl Microbiol 5, 315-326.

Yoshimi, Y., Hiraishi, A. \& Nakamura, K. (1996). Isolation and characterization of Microsphaera multipartita gen. nov., sp. nov., a polysaccharide-accumulating gram-positive bacterium from activated sludge. Int J Syst Bacteriol 46, 519-525.

Zilles, J. L., Peccia, J., Kim, M.-W., Hung, C.-H. \& Noguera, D. R. (2002). Involvement of Rhodocyclus-related organisms in phosphorus removal in full-scale wastewater treatment plants. Appl Environ Microbiol 68, 2763-2769. 